\title{
Factors Affecting National Interests in the Aftermath of Post 1990 Armed Conflict in Nepal
}

\author{
Pitambar Bhandari \\ Assistant Professor, Department of Conflict, Peace and Development Studies, Tribhuvan University \\ mepitambar@gmail.com
}

\section{Article History}

Received September 30, 2020 Accepted October 21, 2020

Keywords Armed conflict, security, national interest, security policy, security vision

\section{Corresponding Editor}

Ramesh Raj Kunwar kunwar.dr@gmail.com

\section{Abstract}

National Interest to a particular country is often shaped and prioritized by various variables including independence, distinctiveness, territorial integrity and socio-cultural determinants. Nepal's national interest depends on the security vision in the aftermath of violent conflict, development initiatives based on utilization of available natural resources and state policies for assuring inclusiveness, social cohesion and justice. Nepal experienced a ten years long armed conflict since 1996 to 2006 that affected a range of social, political and economic dimensions along with security apparatus of the country. Though the fundamental attributes of national interest such as territorial and political sovereignty and the core values remain constant, security policy and strategies are found to be evolving in the nascent democracy often shaped by the ability to identify security threats. With the aim of developing a causal relationship between national interest and security vision, security policy, identification of security threats, quantitative analysis is conducted by adopting SPSS and Karl Pearson's Correlation tools. Moreover, Nepal's new security policy has been analyzed in the aftermath of violent conflict. This paper draws the conclusion that higher the ability of political leaders to identify the security vision, the achievement of national interest is higher. This also depicts if security vision is closely linked with the political values the promotion of national interest is high. Setting the context on political change and the security strategy, it is admitted that new form of government induces additional security concern which if not identifiedmaychallengethemeansofensuringnationalsecurity. 


\section{Concept of security}

Scholars in the field of political science and sociology argue that security seems to be an immanent structural element of society. Security involves a state in which the balanced physical, spiritual, psychical and material existence of an individual and the community as a whole is ensured in relation to other individuals, communities as well as to natural environment. Security relates to a particular society as well as to the international community (Grizold, 1994, p. 39).

As illustrated by Robert McNamara security and development are intrinsically linked. Security means development, security is not military hardware, though it may involve it, security is not traditional military activity, though it may encompass it, security is development and without development there can be no security.

The Palme Commission's report, Common Security: A Blueprint for Survival also viewed "security" as a multidimensional concept- that security must be conceived in broad terms to include economic issues as well as military threats. It stressed the linkage between common security and common prosperity (Capie \&Paul 2002, p. 60).

"A national security policy serves as a common and agreed reference point for a country's decision-makers and helps them keep a reasonable degree of consistency in their day-to-day decisions. It also helps them to prioritise - to keep in mind what is important and what is less so, in terms of both security interests and security objectives. In short, an NSP provides a country's decision-makers with a common basis in their handling of and responses to information and events which represent threats, risks, challenges or opportunities to the country's security understood in a broad sense. The most important benefit of National Security Policy, in fact, may be to have reached a shared understanding on security objectives and priority interests" (Knudsen, 2012, p. 136).

There are two concepts of national security in practice; traditional concept and non-traditional or 'comprehensive' concept. Traditionally, the nation state has been the primary referent object of security. Security has been concerned with protecting territory, or advancing the national interests or core values of states. The traditional security concepts therefore, focused on external threat to the nation-state (Capie \&Paul, 2002. p. 139). "To address external threats, traditional policy responses such as defense preparedness, deterrence, and military alliances have dominated approaches to achieving national security" (Capie \& Paul, p. 281).

Security policy in its broader sense relates to any advance preparations against threats deriving from nature, society and relations among societies. The aim of security policy in this sense is to maintain and to protect the fundamental values of the society and to ensure security from all possible sources of threat. (Grizold, 1994.p. 44).

This paper seeks to have an idea on what are the various factors affecting national interest in post 1990 armed conflict in Nepal?; How is the national security policy formulated?; and, how isnational security policyaddressed throughnationalsecurity strategy to promote national interest? 
In general this paper aims to gather an idea on how the national security policy of Nepal has been formulated and to establish the relationship between security problem identification to protect national interest. In specific, factors affecting national interest in Post 1990 armed conflict in Nepal, the policy formulation process in Nepal in reference to national security policy and identification of the internal and external security threats in post-conflict situation are the concerned areas.

\section{Hypotheses}

The following three hypotheses are set:

- $\quad$ There is a significant relationship between national interest and security vision in Nepal.

- $\quad$ There is a significant relationship between national interest and national security policy process.

- There is a significant relationship between protection of national interest and the identification of security threats in Nepal.

\section{Conceptual framework and the method}

National Security essentially means the state of the health of the nation within which citizens enjoy life, liberty, property and participation in the productive life of society (Dahal, 2008). Policy issue refers to the shaping of a policy in response to a problem and its injection into the process. Approval is the process by which policy passes through formal executive and legislative procedures. Policy implementation is about how policies are carried out (Sarkesian, Williams and Cimbala, 2008:170). In this context of policy issue, approval and implementation, Nepali security sector is often impacted by the frequent regime changes and lack of a concrete security policy before 2016 .

According to the Article 5 (1) of Constitution of Nepal, 2015 "Safeguarding of the freedom, sovereignty, territorial integrity, nationality, independence and dignity of Nepal, the rights of the Nepalese people, border security, economic wellbeing and prosperity shall be the basic elements of the national interest of Nepal."

$\begin{array}{ll}\text { Independent variables } & \text { Dependent variables } \\ \begin{array}{l}\text { - Security vision (Cultural and } \\ \text { political values in Nepal, Peace, } \\ \text { conflict resolution) }\end{array} & \text { National interest } \\ \text { - Security policy process } & \text { - Vital interest } \\ \text { (Political decision and } & \text { - Critical interest } \\ \text { democratic governance) } & \text { - Serious interest } \\ \text { - Identification of security } & \text { - Territorial integrity } \\ \text { threats and security strategy } & \text { Political sovereignty }\end{array}$

Source: Developed by the author on the basis of Knudsen, 2012 and National Security Policy, Nepal, 2016 
While developing this paper, exploratory research design has been used. Features of various security problems are studied and described in case of Nepal. After having information collected and processed, the findings are analyzed basically on the basis of factors promoting national interest. Causal relation between national interests, security vision, policy, strategies of security is examined.

A total of 60 respondents are taken randomly. A set of survey questionnaire is administered to the respondents comprising graduate students in conflict and peace studies who are acquainted with the national security policy process and national interest as a part of their academic courses that covers more than 10 percent of the graduate students adopting the course related to strategic studies and national security in Nepal.

Altogether 10 respondents including former ministers, government officers, political analysts, security experts, civil society members and academicians were interviewed to acquire information.

The collected data were processed and analyzed using both qualitative and quantitative techniques. Quantitative test methods such as SPSS and Karl Pearson's correlation coefficient are used to test the set hypotheses.

\section{Armed Conflict and Security Context in Nepal}

The practice of liberal economy and market based competitive democracy after democratic restorationin 1990reflectingtheinstitutionalreformwashighlyruinedbyintra-party conflict. The armed conflict in Nepal from 1996 to 2006 brought the country into violent stage with Monarchy-Republican, centralized-federal, Ethnicity-Caste and Hinduism-secularism as the major conflict lines.

Bhandari (2016) in the article 'Rearranging the Conflict lines' opines that federal democratic Republic Nepal declared after the amendment of Interim Constitution 2007 received new power dynamics and political players. National parliamentary parties faced splinter groups joining to regional parties 'Madhesi' and other ethnicity based parties before first CA Election. The dominance of regional sentiment over the political ideology formed a major component for intraparty conflict within MFJ, Madhes based party and the result was less representation in the Second CA. However, in the process of constitution making, 'Madhesi' identity became prominent after the sixteen point agreement among the three bigger parties along with MJF (Democratic). The sixteen point agreement though considered the document of reflection of national disaster and political crisis together, institutionalized the movement of 'Madhesi identity'.

The new constitution promulgated in the aftermath of 'Kailali incident' that expressed an unfortunate imagery of 'failed negotiation' at local level and posed threat to national security issue, created new conflict. The strategy of the movement adopted by MJF has uniqueness in the history of political movement in Nepal. First, blockade to the hill and subsequent in the Himalayan region from Terai region slowly manufactured the industry of segregation among constructed 'Madhesi' and 'Pahade'. Although 'Madhes' is purely topographical representation, the protestors tried to amalgamate the cultural and linguistic diversity in the same basket on the base of genealogy. (Bhandari, 2016) 


\section{Formulating National Security Policy and the Nepalese context}

Sarkesian, Wiliams and Cimbala in the book entitled "US National Security: Policymakers, Processes \& Politics" published in 2008 discuss the approaches to the study of national security. According to them "There are three major approaches to the study of national security: the concentric-circle, the elite-versus-participatory policymaking, and the systems analysis; all concentrate on the way in which policy is made.

The concentric-circle approach places the president at the center of the national security policy process. This approach shows the degree of importance of various groups as the "primary objects" of national security policy. (Sarkesian, Wiliams and Cimbala, 2008).

The elite-versus-participatory policymaking approach is based on the view that democracy's basic dilemma is that the policy process is dominated by elites. National security policy is undertaken by elites within the national security establishment, but that elite group must in turn develop support in the broader public. On the one hand, the elites have the skill and access to information to formulate national security policy, in contrast to an uninformed public. On the other hand, for national security policy to be successful in the long run, there must be some degree of participation by the public and political will within the body politic." (Sarkesian, Wiliams and Cimbala, 2008).

Professor of international law, Vojin Dimitrijevic, identified five characteristic features which he considers the basic elements of national security:

- $\quad$ ensuring the existence of the state as a political community, existence of the nation (which is not identical with the existence of a particular state) and the physical survival of its population;

- $\quad$ protecting territorial integrity as the basic right of the state;

- maintaining political independence as an attribute of internationally recognized national status of the state;

- $\quad$ ensuring quality of life;

- embedding of the "vital interest" of the state in the national security policy. (Grizold, 1994. p. 40)

\section{Provisions of National Security Policy 2073 BS}

The major provisions in National security policy 2073 BS are:

Achieve balance economic development to raise living standard of the people.

- $\quad$ Strengthening national unity through equality and coexistence among various religions, cultures, cast, community, origin and languages.

- Utilization of natural resources with a view to fulfilling national interests.

- Maintaining clean environment.

- $\quad$ System of reservation will be implemented for socially backward indigenous, Madhesi, Dalits and marginalized groups.

- $\quad$ Special policy will be implemented for mobilization of youth in country's development.

- $\quad$ Foreign policy of Nepal will be based on Charter of the UN, Non-align ment, principle of Panchasheel, international laws and norms of world peace.

- Institutionalize peace on the basis of international norms. 
Security is the multidimensional aspect that covers the range of National sovereignty, integrity and social, economic, cultural and human security.

Section 1.3 is about the need assessment of National security Policy. It includes:

- To protect sovereignty, territorial integrity, national unity, freedom and social cohesion and create the conducive environment to utilize the national resources.

- $\quad$ To establish the credibility that state addresses natural risks and threats.

- To increase the effectiveness of security sector by providing necessary modern technology and equipment for security mechanism and structure, make them strengthened and increase the contribution and active participation of all the concerned.

- $\quad$ To direct the implementation of policies adopted by the state.

- To create internal consensus among all classes, communities and sectors in the country.

- $\quad$ To build regional and international trust and cooperation for national security and world peace.

- To promote co-existence, tolerance and cohesion among all the religious, cultural, linguistic and territorial communities in Nepal.

- $\quad$ To increase the national security capacity and protect the country from communication and psychological attack by utilizing rapid development of communication and technology in the world.

- $\quad$ To control and defeat potential security threats and to conduct state security system in a coherent, coordinating and planned way.

- To create the situation in which national security mechanism could be mobilized in an efficient way during the time of both peace and conflict and ensure that the country as a whole endorses it.

- $\quad$ To achieve national objective through protection, preservation and promotion of vital national interests by addressing the potentialities and challenges; geopolitical situation; and changing international, regional and national security environment.

According to National Security Policy 2073, section 1.6 National interests, concern and security issues are enlisted as:

\section{Issues of vital national interests}

- Protection of national independence, sovereignty, territorial integrity, national unity, dignity, self-determination and people's security.

- $\quad$ Protection and preservation of federal democratic republic.

- National unity, social harmony and religious tolerance.

- $\quad$ Protection of national identity and existence.

- $\quad$ Protection of people's liberty and fundamental human rights.

- $\quad$ Sustainable peace, security and political stability.

- Conservation of environment and climate.

- Preservation of natural resources including water resource and heritage and their utilization in national interest. 
- $\quad$ Promotion of world peace through contribution in international and regional security.

- $\quad$ Creation of reliable condition that the land of Nepal will not be used against any other country

- $\quad$ Protection of rule of law.

- $\quad$ Foreign policy based on UN Charter and principle of Panchasheela.

\section{Issues concerning strategic interests}

- Adoption of appropriate strategy and work procedure for the protection of issues of vital concerns

- $\quad$ Social development, prosperity, harmony and coherence ; and tolerable civil society

- Development of national capacity

- Development of people's living standard

- $\quad$ Effectiveness of good governance and public administration

- Minimization of social and economic imbalance that exists between provincial and local level

- Development and utilization of science and technology

- $\quad$ Appropriate security system for economic prosperity

- Control of organized crime and illegal immigration

- Minimizing and mitigating natural disaster and industrial hazards

- $\quad$ Mitigating extrajudicial activities and end of the bases for that

- $\quad$ Control and mitigate terrorism and secessionism

- $\quad$ Control of use of illegal arms and explosives

- Development of international and regional cooperation.

\section{Components of national interest}

National Interest to a particular country is often shaped and prioritized by various variables including independence, distinctiveness, territorial integrity and socio-cultural determinants. Nepal's national interest depends on the security vision in the aftermath of violent conflict, development initiatives based on utilization of available natural resources and state policies for assuring inclusiveness, social cohesion and justice. "Security interests of individual states should be harmonized, adjusted and linked to the interests of the whole international community." (Grizold, 1994.p.38)

Table 1: Components of National Interest

\begin{tabular}{|l|c|c|c|}
\hline & $\mathrm{N}$ & Disagree \% & Agree \% \\
\hline $\begin{array}{l}\text { Current security vision and security strategy is found } \\
\text { compatible with vital national interest }\end{array}$ & 60 & 35 & 65. \\
\hline $\begin{array}{l}\text { Cultural and political value system in post-conflict Nepal } \\
\text { is in accordance with initiatives promoting national unity } \\
\text { and social cohesion }\end{array}$ & 60 & 29. & 71 \\
\hline $\begin{array}{l}\text { Political will and leadership among parties is found to } \\
\text { support sustainable peace and political stability }\end{array}$ & 60 & 57 & 43 \\
\hline
\end{tabular}




\begin{tabular}{|l|l|l|l|}
\hline $\begin{array}{l}\text { There are initiatives to protect human rights and people's } \\
\text { freedom after the promulgation of new constitution } \\
\text { Development approach is focused on the utilization of }\end{array}$ & 60 & 15.0000 & 85.00000 \\
\hline $\begin{array}{l}\text { water and other natural resources to fulfill national interest } \\
\text { Post-conflict governance is effective in terms of public } \\
\text { administration }\end{array}$ & 60 & 44.0000 & 56.00000 \\
\hline $\begin{array}{l}\text { There are not serious challenges to rule of law for } \\
\text { promoting national interest }\end{array}$ & 60 & 62.0000 & 38.00000 \\
\hline $\begin{array}{l}\text { State policies and programs in the post-conflict situation } \\
\text { favors inclusiveness, social cohesion and social justice }\end{array}$ & 60 & 25.0000 & 75.00000 \\
\hline $\begin{array}{l}\text { State policies and programs in the post-conflict situation } \\
\text { favor inclusiveness, social cohesion and social justice }\end{array}$ & 60 & 30.0000 & 70.00000 \\
\hline inclusiveness, social cohesion and social justice & & & \\
\hline
\end{tabular}

Source: Field study, 2017

The cultural and political value system in Nepal holds shifting character after ten years long armed conflict, 1996-2006 A.D.

\section{Correlation among Security Vision, Policy Process, Threats and National Interest}

The correlation matrix among the variables shows that national interest in Nepal is moderately correlated with the security vision set.

The Pearson's correlation coefficient is .471 .

Table 2: Correlations among variables

\begin{tabular}{|l|l|c|c|c|c|}
\hline \multirow{2}{*}{} & $\begin{array}{l}\text { National } \\
\text { interest }\end{array}$ & $\begin{array}{l}\text { Security } \\
\text { vision }\end{array}$ & $\begin{array}{l}\text { National security } \\
\text { policy process }\end{array}$ & $\begin{array}{l}\text { Security } \\
\text { Threats }\end{array}$ \\
\hline \multirow{4}{*}{ National Interest } & Pearson Correlation & 1 & .471 & -.087 & .312 \\
\cline { 2 - 6 } & Sig. (2-tailed) & & .013 & .646. & 120 \\
\cline { 2 - 6 } & $\mathrm{N}$ & 32 & 27 & 30 & 26 \\
\hline \multirow{3}{*}{ Security vision } & Pearson Correlation & $.471 * *$ & 1 & -.251 & .367 \\
\cline { 2 - 6 } & Sig. (2-tailed) & .013 & & .134 & .036 \\
\cline { 2 - 6 } & $\mathrm{N}$ & 27 & 43 & 37 & 33 \\
\hline \multirow{3}{*}{\begin{tabular}{l} 
Policy Process \\
\cline { 2 - 6 }
\end{tabular}} & Pearson Correlation & $-.087 * *$ & -.251 & 1 & .300 \\
\cline { 2 - 6 } & Sig. (2-tailed) & .646 & .134 & .089 & \\
\cline { 2 - 6 } & $\mathrm{N}$ & 30 & 37 & 48 & 33 \\
\hline Identification of & Pearson Correlation & $.312 * *$ & $.367 * *$ & .300 & 1 \\
\cline { 2 - 6 } & Sig. (2-tailed) & .120 & .036 & .089 & 37 \\
\cline { 2 - 6 } & $\mathrm{N}$ & 26 & 33 & 33 & 37 \\
\hline
\end{tabular}

Significance at 5 percent

Source: Field survey, 2017 
The study shows that Pearson correlation coefficient between national interest and national security policy process is -.087 . With this correlation among the variables, it is justified that the relationship among the variables can be further analyzed.

\section{Security vision and national interest}

According to Knudsen (2012), security vision of any country can be analyzed in terms of maintaining peace and order. The quest for peace and stability is further shaped by existing cultural and political value system of the country.

Table 3: Security vision and national interest

\begin{tabular}{|c|c|c|c|}
\hline & $\begin{array}{l}\text { Unstandardized } \\
\text { Coefficients }\end{array}$ & & \\
\hline & $\mathrm{B}$ & $\mathrm{T}$ & Sig. \\
\hline (Constant) & 6.047 & 1.787 & .091 \\
\hline $\begin{array}{l}\text { Political party leaders are able to identify security vision } \\
\text { Government officers consider security vision in }\end{array}$ & 1.069 & .756 & .459 \\
\hline $\begin{array}{l}\text { decision making process in Nepal } \\
\text { Civil society leaders in Nepal have considered }\end{array}$ & 2.135 & 1.432 & .169 \\
\hline $\begin{array}{l}\text { security vision as a core agenda in democracy } \\
\text { Security vision is closely linked with political values }\end{array}$ & -2.006 & -1.469 & .159 \\
\hline (consensus, competition and commitment) in Nepal & 3.086 & 1.620 & .123 \\
\hline $\begin{array}{l}\text { Security vision is closely linked with cultural diversity } \\
\text { in Nepal }\end{array}$ & -.754 & -.241 & .813 \\
\hline $\begin{array}{l}\text { Security vision has become the guiding vision while } \\
\text { facing politically contentious issues among political actors }\end{array}$ & -1.093 & -.795 & .437 \\
\hline \multicolumn{4}{|l|}{ Policy makers consider economic capability of Nepal as } \\
\hline driving factor of national interest & 1.576 & .787 & .442 \\
\hline $\begin{array}{l}\text { Military capability of Nepal is considered as prime } \\
\text { factors for defining national interest }\end{array}$ & 1.038 & 1.023 & .320 \\
\hline $\mathrm{R}$ & 41.2 & & \\
\hline Watson & 2.285 & & \\
\hline $\mathrm{F}$ & 1.850 & & \\
\hline
\end{tabular}

Source: Field survey, 2017

Political Party Leaders and Security Vision

The $\beta$ value for ability of political party leaders in identifying security vision to promote national interest is 1.069 . This shows that higher the ability of leaders to identify the security vision, the achievement of national interest is higher.

However one of the Key Informants stated that the political vision and coherence among political leaders is lacking while shaping the security vision. "A weak leadership or 
excessive politics of conflict and confrontation provides a fertile ground for undue external influence. Nepal's national interest is best served by a foreign policy of friendship with all and hostility towards none" (Simkhada, 2011).

\section{Government officer and security vision}

The higher the government officers consider security vision in decision making process, the higher would be the chances for promoting national interest. The $\beta$ coefficient is 2.185 and $\beta$-value is $17 \%$.

Civil society leaders considering security vision vibrant civil society is considered as fundamental ingredient of democracy. In Nepal, the study shows that if civil society leaders consider security vision is core agenda, the promotion of national interest would be high as the $\beta$ coefficient is -2.006 at $\beta$-value $16 \%$.

\section{Political values, cultural diversity and security vision}

The political values in the aftermath of armed conflict in Nepal are often guided by consensus among the leaders, competition among the political parties. The study depicts that if security vision is closely linked with the political values the promotion of national interest is high. The cultural diversity in Nepal recognized withidentity and participation in the aftermath of conflict should be closely linked with security vision for the promotion of national interest.

Similarly, the study result shows that, if security vision becomes the guiding vision while facing politically contentious issues among political actors, the chances for promoting national interest is high. The $\beta$ coefficient for policy makes considering economic capability in decision making in relation to national interest is 1.576 at $\beta$-value $45 \%$. Thus there is significant relationship between policy makes considering economic capability and achievement of national interest. Military capability if considered as prime factor in security vision, the promotion of national interest is formed in sufficient relationship.

\section{Security Policy Process and National Interest}

The public policy process in Nepal is often based on top-down approach. In this context, it is essential to examine the relationship between security policy process and the achievement of national interest.

The study result shows that if the people are aware about internal and external security threats and are clear about vulnerabilities of natural disaster, then the national interest achievement would be high.

The $\beta$ coefficient on the perception of the respondents on awareness about the security policy formulation is -0.157 and $\beta$-value $92 \%$. The study shows that if the involvement of people in security related programs and policies at security policy formulation process, dissemination of security challenges would provide significant relationship to the promotion of national interest. 
The analysis further shows that if there is the public hearing process related to security policy and bureaucrats and politicians are highly engaged in policy formulation, then the achievement of national interest is higher.

"It sounds hypocritical to talk and preach about subjective concepts like sovereignty, freedom, independence, national unity, and democracy in front of starving peoples who comprise a great majority of the Nepalese population, Therefore, addressing and meeting those basic human needs of the Nepalese form the most vital national interest of Nepal" (Limbu, 2011).

Table 4: Security policy process and national interest

\begin{tabular}{|c|c|c|c|}
\hline & \begin{tabular}{|l|} 
Unstandardized \\
Coefficients
\end{tabular} & & \\
\hline & $\mathrm{B}$ & $\mathrm{T}$ & Sig. \\
\hline (Constant) & 19.435 & 2.761 & .012 \\
\hline I know about the internal security threats in Nepal & -2.016 & -.664 & .514 \\
\hline I have idea about external security threats in Nepal & 1.586 & .417 & .681 \\
\hline $\begin{array}{l}\text { I am clear about potentials for serious natural disas- } \\
\text { ters in Nepal }\end{array}$ & $-2.650-$ & 609 & .550 \\
\hline I am aware about the security policy formulation & -.157 & -.096 & .924 \\
\hline $\begin{array}{l}\text { I have been involved in national security related } \\
\text { programs and activities }\end{array}$ & -.215 & -.153 & .880 \\
\hline I have read about the security challenges in newspaper & 1.064 & .691 & .497 \\
\hline $\begin{array}{l}\text { I have seen bureaucrats and politicians engaged in } \\
\text { security policy formulation }\end{array}$ & -1.874 & -1.472 & .156 \\
\hline $\begin{array}{l}\text { I have an experience of being engaged in public } \\
\text { hearing process related to security policy }\end{array}$ & .438 & .318 & .754 \\
\hline $\begin{array}{l}\text { I know about the legal procedures for national } \\
\text { security decision making }\end{array}$ & .992 & .610 & .549 \\
\hline $\mathrm{R}$ & 17.4 & & \\
\hline Durbin Watson & 2.045 & & \\
\hline $\mathrm{F}$ & .468 & & \\
\hline
\end{tabular}

Source: Field survey, 2017

Almond (1956) claims that "A sound program of public opinion development in the field of national security policy would have as its main aim the creation of an attentive public competent to handle the issues of national security policy. This means in very specific terms four lines of action: (1) the introduction of problems of military policy into university curricula and the development of military scholarship in the universities to produce a leadership with a basic competence to understand the issues of security policy. 
(2) The development of soundly trained military specialists in the media of communication to ensure that the issues of security policy will be rapidly and accurately transmitted throughout the significant strata of the population. (3) The training of specialists in problems of military policy in the major interest groups to ensure more responsible interest group pressures. (4) The development of scholarship in political and military affairs among the military leadership to create a homogeneous leadership capable of organizing and articulating the issues in public."

\section{Identification of security threats and national interest}

The changing context of political and governance sector faces new trends in security challenges. Any nation-state with shifting regimes and political structures identifies new forms of security challenges not limited to the internal cases. Identification of security threats forms an important pre-condition for identifying factors promoting national interest. According to Dahal $(2012$, p.1) "The sources of threat can be extra-systemic (inter-state tension, cross-border terrorism, unwanted immigration, climate change, fuel and financial crises, refugees etc.) or intra-systemic (civil war, poverty trap, inequality and exclusion of citizens from ecological, social, economic and political resources)."

Table 5: Identification of security threats and national interests

\begin{tabular}{|c|c|c|c|}
\hline & $\begin{array}{l}\text { Unstandardized } \\
\text { Coefficients }\end{array}$ & & \\
\hline & $\mathrm{B}$ & $\mathrm{T}$ & Sig. \\
\hline (Constant) & 8.798 & 1.412 & .177 \\
\hline $\begin{array}{l}\text { New security challenges have emerged after the } \\
\text { violent conflict }\end{array}$ & .438 & .194 & .849 \\
\hline $\begin{array}{l}\text { Activities for controlling arms proliferation has } \\
\text { become the agenda for government }\end{array}$ & .990 & .777 & .449 \\
\hline $\begin{array}{l}\text { Public attitude has become more aggressive after the } \\
\text { conflict situation in Nepal }\end{array}$ & 2.805 & 1.596 & .130 \\
\hline $\begin{array}{l}\text { Introduction of federal system has brought unexpect- } \\
\text { ed threats in security context }\end{array}$ & -.231 & -.161 & .874 \\
\hline $\begin{array}{l}\text { Political transitions have provided the ground for } \\
\text { unexpected challenges to security context }\end{array}$ & -2.767 & -1.363 & .192 \\
\hline $\begin{array}{l}\text { Foreign engagement in post conflict Nepal has intro- } \\
\text { duced serious security concern }\end{array}$ & -.356 & -.247 & .808 \\
\hline $\begin{array}{l}\text { The coordination among the security agencies is } \\
\text { found effective while dealing with security problems }\end{array}$ & -1.531 & -1.184 & .254 \\
\hline $\begin{array}{l}\text { National Security Council is effective to take } \\
\text { decisions on security matter }\end{array}$ & 2.836 & 2.637 & .018 \\
\hline $\begin{array}{l}\text { Inter-ministerial coordination is effective in dealing } \\
\text { with security problems }\end{array}$ & 1.243 & 1.087 & .293 \\
\hline R Square & 45.9 & & \\
\hline Durbin Watson & 2.290 & & \\
\hline $\mathrm{F}$ & 1.508 & & \\
\hline
\end{tabular}


Source: Field survey, 2017

The findings shows that after the armed conflict in Nepal, new security challenges have emerged and the identification of those challenges are significant in promoting national interest. National interestachievement is also significantly dependent on the activities controlling arms proliferation by the government.

If the public attitude becomes more aggressive, it also posits threats in national interests. In general, the post conflict situation is characterized by high expectation of people from the government and political violence is increased. Moreover, the new form of government induces additional security concern which if not identified may challenge the means of ensuring national security. The political transitions, foreign engagement in the peace process and constitution making process must be identified and analyzed in terms of achieving national interest immediate after the violent conflict.

If the coordination among security agencies and inter-ministerial coordination is effective in dealing with security problems then national interest could be met in higher degree. Dahal (2012) in relation to the loyalty of security agencies posits that "Nepal's political institutions now rest on the commitment to popular sovereignty, parliamentary supremacy and politicalopenness. But, the political process of Nepalrevolves around powerful personalities rather than institutions. The familial and dynastic succession of leadership has bred a patrimonial culture. Poor political institutionalization has blurred the boundaries between various institutions of society. From the unification days until recently there is a continuity of the state institutions, such as monarchy, Nepal Army, police, bureaucracy, tradition and law and discontinuity and fragmentation of civic institutions. Lack of a balance between the state and society created authoritarian culture in the nation. But, the security agencies of the nation have expressed absolute loyalty to those in power under all regimes-- monarchy, anarchy, oligarchy, liberals and even communist-led regime and helped to maintain the unity and security of the nation through state-orientation notion of security politics. Their preference for loyalty, discipline, patriotism and hierarchy has earned their image abroad in peace keeping missions. "However, the study shows that more effectiveness in decision of National Security Council does not necessarily promote national interest.

Baral (1986, p. 1218) opines that "Nepali security policy hinges on three areas: a modest and correct Indo Nepal and Sino-Nepal relationship, internal cohesion, and the successful handling of extra-regional and regional policies for maximizing economic benefits. Nepal's assertive foreign policy of the 1950s and 1960s has shown its limits in the past decade or so and is highly unlikely to produce any result. Even if Sino-Indian relations continue to be competitive, if not characterized by intense hostility, Nepal has to deal with the two immediate neighbors with great restraint and dexterity. A relationship marked by civility may enhance the prospects of national security better than a policy of expediency. Moreover, Nepal should also be careful that no external forces play active roles on its domestic front. If Nepali power elites become too enthusiastic about averting domestic crises through their external policies without giving any consideration to their roots, the external forces may be inclined to capitalize on the situation in their own favor." 


\section{Conclusion}

Nepal's national interest is dependent on security vision and national security policy. Better achievement of national interest depends on visionary political leadership, recognition ofsocialandculturaldiversityofthenationandability toidentifyinternalandexternal security threats. Moreover, effective coordination among core security agencies is the indicator for achieving national interest. The political values in the aftermath of armed conflict in Nepal are often guided by consensus among the leaders, competition among the political parties. The study depicts that if security vision is closely linked with the political values the promotion of national interest is high. The cultural diversity in Nepal recognized with identity and participation in the aftermath of conflict should be closely linked with security vision for the promotion of national interest.

Similarly, the study result shows that, if security vision becomes the guiding vision while facing politically contentious issues among political actors, the chances for promoting national interest is high.

The public policy process in Nepal is often based on top-down approach. In this context, it is essential to examine the relationship between security policy process and the achievement of national interest.

The study result shows that if the people are aware about internal and external security threats and are clear about vulnerabilities of natural disaster, then the national interest achievement would be high.

\section{References}

Almond, G.A. (1956). American Association for Public Opinion Research. The Public Opinion Quarterly, 20 (2), 371-378.

Baral, L.R. (1986). Nepal's Security Policy and South Asian Regionalism. Asian Survey, $26(11), 1207-1219$.

Bhandari, P. (Jan 3, 2016). Rearranging the Conflict Lines. Setopati.

Bhattarai, R. (2009). The concept of Human security and Changing Security Dynamics in Nepal. Bhattarai, R. \& Cave, R. (ed.). Changing security dynamics in Nepal. Kathmandu, Nepal. NIPS.

Bhattarai, R. (2010). Broadening Nepal's Security Agendas: Armed Conflict, Migration and Environment Perspectives. Bhattarai, R. \& Wagle, G.S. (ed.). Emerging Security Challenges of Nepal (pp. 165-218). Kathmandu,Nepal : NIPS

Capie, David and Paul Evans. The Asia-Pacific Security Lexicon. Singapore: Institute of Southeast Asian Studies. 2002.

Canada's National Security Policy: http://www.publicsafety.gc.ca/pol/ns/secpol04-en.asp

Dahal, D.R. (2012). National Security: Security Sector Reforms and Civil-Security Relations in Nepal. Presentation made at a seminar organized by Nepal 
Ex-Policemen Organization and Friedrich-Ebert-Stiftung, November 16, 2008, and Nepal Police Academy in Kathmandu on November 20.

Grizold, A. (1994). The Concept of National Security in the Contemporary world. International Journal on World Peace, 11 (3), 37-53.

Huntington, Samuel P. Soldier and the State: The Theory and Politics of Civil -Military Relations, Dehradun: Natraj Publishers. 2005 First Edition

Jordan, Amos A., William J. Taylor and Michael J. Mazarr. American National Security. Baltimore: The John Hopkins University Press. 1999 (Fifth Edition).

Knudsen, B.B. (2012). Developing a National Security Policy/Strategy: A Roadmap. Security and Peace, 30 (3), 135-140.

Limbu, R. (2011). Challenges to National Security and Safeguarding National Interests. In Delinic, T., \& Pandey, N.N. (Eds.), Nepal's National Interests: Foreign Policy, Internal Security, Federalism, Energy-economy (pp. 53-54). Kathmandu: Centre for South Asian Studies (CSAS).

Lippman, W. (1943). US Foreign Policy: Shield of the Republic. Boston: Little Brown. National Security Policy, Nepal, 2016.

Sarkesian, S. C., Williams J. A., Stephen J. Cimbala, S. J. (2002). US National Security: Policymakers, Processes and Politics. London: Lynne Reinner Publishers. 2002

Schaffer, T. (1998) Security in India's Neighbourhood, The View from Washington. ORF Strategic TrendsStares, Paul B. Ed. The New Security Agenda: A Global Survey. Tokyo: Japan Centre for International Exchange. 1998

Simkhada, S.R. (2011). Nepal's National Interest and Foreign Policy. In Delinic, T., \& Pandey, N.N. (Eds.), Nepal's National Interests: Foreign Policy, Internal Security, Federalism, Energy-economy (pp. 23-24). Kathmandu: Centre for South Asian Studies (CSAS). 